4-10-2017

\title{
What the Future Holds: The Changing Landscape of Federal Indian Policy
}

Kevin Washburn

University of New Mexico - School of Law

Follow this and additional works at: https://digitalrepository.unm.edu/law_facultyscholarship

Part of the Indian and Aboriginal Law Commons

\section{Recommended Citation}

Kevin Washburn, What the Future Holds: The Changing Landscape of Federal Indian Policy, 130 Harvard Law Review Forum 200 (2017).

Available at: https://digitalrepository.unm.edu/law_facultyscholarship/411

This Article is brought to you for free and open access by the UNM School of Law at UNM Digital Repository. It has been accepted for inclusion in Faculty Scholarship by an authorized administrator of UNM Digital Repository. For more information, please contact amywinter@unm.edu, Isloane@salud.unm.edu,sarahrk@unm.edu.

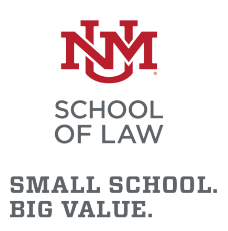

BIG VALUE. 


\title{
WHAT THE FUTURE HOLDS: THE CHANGING LANDSCAPE OF FEDERAL INDIAN POLICY
}

\author{
Kevin K. Washburn* \\ INTRODUCTION
}

For nearly two hundred years, the United States has been deemed to have legal and moral obligations to the American Indian nations that shared North America - sometimes voluntarily, sometimes not with immigrants. Today, these various federal obligations, collectively known as "treaty and trust responsibilities," are no less weighty as the United States has grown to become the richest economy in the world. However, the boundaries of these responsibilities as well as their content have evolved dramatically with changes in federal policy in recent decades.

For much of American history, the federal trust responsibility was characterized by broadening federal administrative control over Indian tribes, with federal officials making most of the important decisions on Indian reservations and diminishing tribal governmental authority. More recently, however, federal control has been receding and giving way to a gradual restoration of tribal authority. More and more, the federal government defers to tribal priorities and tribal decisionmaking. While this development has been positive for tribes, it has come at a cost.

As tribal control has increased, courts have been less willing to hold the federal government responsible for its actions (and inactions) in Indian country. Indeed, if the most compelling way to determine the measure of a responsibility is to weigh the costs of its breach, the federal trust responsibility has been diminished. Judicial enforcement of the trust responsibility today is more rare and limited in scope.

Proclaiming the death of the trust responsibility, however, is premature. While courts have narrowed the legal enforceability of the trust responsibility to tribes, the political branches have expanded the meaning of the trust responsibility. Congress and the President have invigorated it with increased federal funding to provide the services and programs required to meet it. They have also settled dozens of breachof-trust actions by tribes that might otherwise have been successfully defended by the federal government in the courts. In some ways, meaningful fulfillment of the federal trust responsibility has been relocated from the courts to the political branches.

\footnotetext{
* Regents Professor of Law, University of New Mexico School of Law.
} 
More importantly, the political branches have come to view the content of the trust responsibility differently. The obligations under the federal trust responsibility have evolved from a paternalistic model in which the federal government provides services and programs and makes decisions for impoverished Native Americans, to an understanding that the trust responsibility obliges the federal government to support and revitalize tribal governments and even advocate and protect tribal sovereign powers. Congress and the executive branch have restored tribal powers, for example, by broadly recognizing tribal felony criminal jurisdiction over American Indians ${ }^{1}$ and even recognizing limited tribal criminal jurisdiction over non-Indians, ${ }^{2}$ reversing longstanding federal policy.

More importantly, in place of federal programs and services, the last fifty years have been characterized by the growth of federal contracting with tribes to perform federal trust functions. Today, billions of dollars of federal appropriations are spent not by the federal government, but by tribes that have contracted to provide federal services to Indian people through so-called "tribal self-determination contracts." In other words, tribes are being paid by the federal government to exercise federal governance powers over Indian lands and people.

In general, the new model has been very successful. As tribal governmental powers have increased and tribes have entered contracts to perform more federal functions, tribal governments have proven more institutionally competent than the federal government in serving Indian people. ${ }^{3}$ Consequently, while federal judicial interpretations of the trust responsibility have rendered the federal government less legally accountable to Indian people, the political branches have shifted these responsibilities to tribal governments that are much more accountable to Indian people. Today, on many reservations, the United States has been relegated to "principal underwriter" of many of the services required under the trust responsibility. ${ }^{4}$ As the federal trust responsibility has come to be seen in this new light, Indian people have gained greater control over their own destinies.

\footnotetext{
1 Tribal Law and Order Act of 20I0, Pub. L. No. III-2II, tit. VII, § 234, I 24 Stat. 2258 , $2279-80$ (codified as amended at 25 U.S.C. $§$ I 302 (20I2)) (restoring tribal felony jurisdiction over Indians).

2 Violence Against Women Reauthorization Act of 2013, Pub. L. No. II3-4, tit. IX, sec. 904, $\S 204(\mathrm{~b})(\mathrm{I})$, I 27 Stat. 54, I2 I (codified at 25 U.S.C. § I304(b)(I) (Supp. I 20I4)) (restoring tribal criminal jurisdiction over non-Indians who commit certain acts of domestic violence on Indian lands).

3 See generally Kevin K. Washburn, American Indians, Crime, and the Law, I04 MicH. L. REV. 709 (2006).

4 And on some reservations, due to gaming or natural resources, the federal government is no longer even the "principal" underwriter.
} 
The restoration of tribes to functional sovereigns with broad powers funded by congressional appropriations under the federal trust responsibility, however, necessarily raises new issues. As tribal governments have begun to exercise substantial power, tribal decisions have begun to have more significant consequences and have produced confusion about federal and tribal roles and responsibilities. For example, should the federal government be liable to Indian people for actions of the tribal government? And what is the obligation of a tribal government to its own people and others for human rights violations and other wrongs? As tribal powers have grown, federal policy has come full circle, with some commentators asking for new federal oversight of tribal governments.

This Essay briefly explains federal Indian policy at this point in history and looks to the future. Part I traces the recent rise of tribal self-governance. Part II traces the development of the trust responsibility and its recent diminishment in the courts. Part III explains what these countervailing developments mean for the trust doctrine today and explain how it has evolved to support tribal self-governance and a remarkable tribal renaissance. This Part also identifies the important new norms that have displaced paternalism in federal Indian policy. Part IV explains how vestiges of paternalism continue to cast a shadow over true tribal self-governance as the new self-governance model has posed new obstacles and subjected tribes to new scrutiny. Finally, it identifies some of the harder questions - and competing interests tribes must confront as more powerful self-governing sovereigns.

\section{The RENAISSANCE IN TRIBAL SELF-GovernANCE}

After more than two centuries of persisting side by side with the federal government, tribal governments in the United States today have more authority and relative economic power than any time since the earliest days of that relationship. Tribes have been experiencing a renaissance, not just economically, but culturally and governmentally. How did this come to be?

In the broad arc of history, the tribal renaissance was somewhat unexpected, at least to those unacquainted with tribal nations. Through a series of federal Indian policies, the United States sought to displace or even to exterminate Indian people, and ultimately, after admitting defeat in these more aggressive efforts, to assimilate Indian people into the broader polity by distributing their property and giving them American citizenship. ${ }^{5}$ Yet Indian tribes survived all of these ef-

\footnotetext{
5 See Cohen's Handbook of FEderal Indian LAw § I.06, at 84-93 (Nell Jessup New-
} ton et al. eds., 20I2 ed.) [hereinafter COHEN's HANDBOOK]. 
forts. As the United States pursued manifest destiny, Indian people and their governing traditions persisted.

While Indian persistence underlies the modern renaissance in tribal governments, its federal roots spring from the Indian Reorganization Act of $1934^{6}$ (IRA), characterized as the "Indian New Deal." In the IRA, Congress explicitly rejected previous federal efforts to allot Indian lands and eviscerate tribal governments. The IRA encouraged tribes to adopt constitutional forms of government, and it created tools for tribal economic development, such as federally chartered corporations. $^{7}$

The IRA represented a rare moment in American history. At a time of American humility in the wake of the Great Depression, the IRA represented federal acknowledgement of the limits of federal power in addressing "the Indian question" and underscored the crucial role of tribal governments in serving Indian people. For federal policy, it expressed an updated view of the federal trust responsibility.

The IRA approach was controversial and was spearheaded by federal officials who embraced views that were perhaps more progressive than the views of most American people. While the IRA was never repealed and indeed most of its provisions remain in effect today, it was short lived and followed soon after World War II by an effort, partially successful, to terminate many tribal governments and fully assimilate Indian people. ${ }^{8}$

Over the more recent past, since the I960s and '70s, Congress and the executive branch have returned to the New Deal Era's embrace of tribal governments first seen in the IRA. The idea began with President Lyndon Johnson's War on Poverty and the much broader notion that poor communities should be empowered to lift themselves up. ${ }^{9}$ In the early days of the War on Poverty, federal policy was not so much seeking to embrace tribal sovereignty as support grassroots community action organizations by empowering them to be creative in finding ways to lift their communities from poverty. Federal policymakers did not trust entrenched local governments to accomplish these objectives so they reached out beyond mayors and city administrations to community groups. Tribal communities were swept up in these efforts and obtained funding precisely because they were not conceived of as entrenched, established governments. It was President Nixon's administration that focused the grassroots self-determination idea very spe-

\footnotetext{
6 Pub. L. No. $73-383$, ch. 576,48 Stat. 984 (codified as amended at 25 U.S.C. $\S \S 46 \mathrm{I}-479$ (20I2)).

7 See Cohen's HANDBOoK, supra note $5, \S$ I.05, at 79-84.

8 See id § 1.06, at 84-93.

9 Kevin K. Washburn, Tribal Self-Determination at the Crossroads, 38 ConN. L. REV. 777 , 788-9I (2006).
} 
cifically on Indian tribes and began again to treat tribes as governments. ${ }^{10}$

The first major piece of legislation developed under this new approach was Public Law 93-638, the Indian Self-Determination Act of I $975 .{ }^{11}$ Under this law, Indian tribes could contract to run Bureau of Indian Affairs (BIA) services or Indian Health Service (IHS) programs for their own tribal members. Under such a contract, known as a "638 contract" or "self-determination contract," a tribe would step into the shoes of the federal government and use tribal employees to run federal programs with federal funding. Under such a contract, a tribe would receive the federal government's share of the agency's appropriation for this work, which primarily covered employee salaries.

Implementing the new policy was difficult at first. The BIA was more than a century old. Any dramatic change to a government agency with such an established culture would have been challenging, but the difficulty of this initiative was exacerbated by the fact that BIA officials who negotiated tribal self-determination contracts were sometimes negotiating the end of their own employment, at least at their present location. This dampened the enthusiasm among some federal employees. Over the long term, however, even the BIA has embraced the contracting of federal functions on Indian reservations by Indian tribes. (The IHS seems to remain somewhat resistant, perhaps because the culture in which doctors and healthcare professionals live inculcates a deep personal responsibility for saving the world one human being at a time and resists contracting out that very important mission.)

Gradually, the tribal self-determination program was broadened and recast as "self-governance." 12 Today, this new approach is widely hailed as a significant improvement in federal Indian policy and a central driver of the decades-long renaissance of tribal governments. In 2015 , tribes have contracted around $\$$ I.6 billion in programs from the Indian Health Services. ${ }^{13}$ Measured by appropriations, over one-third of IHS's programs are now being contracted and run by Indian tribes themselves. ${ }^{14}$ The federal workforce has adjusted accordingly. To illustrate the scope of changes, note that in I983, the BIA directly em-

\footnotetext{
10 Special Message to the Congress on Indian Affairs, I970 PUB. PAPERS 564, 564-67, 576 (July 8, I970) [hereinafter Special Message on Indian Affairs].

11 More formally known as the Indian Self-Determination and Education Assistance Act, Pub. L. No. $98-638,88$ Stat. 2203 (codified as amended at 25 U.S.C. $\$ \$ 45^{\circ}-450 \mathrm{n}, 455-458 \mathrm{e}$ ).

12 See Geoffrey D. Strommer \& Stephen D. Osborne, The History, Status, and Future of Tribal Self-Governance Under the Indian Self-Determination and Education Assistance Act, 39 AM. INDIAN L. REV. I, 29-40 (20I4-I5).

13 Id. at 49 .

14 See id.
} 
ployed approximately I5,000 people. ${ }^{15}$ As of 2014 , employment for the BIA and a sister agency, the Bureau of Indian Education, totaled approximately 8700 , even though appropriations had increased even in real dollars over the same period of time. ${ }^{16}$

While federal self-determination laws provided a more favorable institutional structure in which tribal governments could thrive within the American system, Indian gaming has underwritten some of their success, at least for more than one-third of American Indian tribes ${ }^{17}$ that have gaming operations. Indeed, for some tribes, the revenues from contracting for federal programs pales in comparison to revenues from Indian gaming, which developed in the I970s and I980s, and has become a nearly $\$ 30$ billion industry. ${ }^{18}$ Gaming revenues allow some tribes to supplement their federal contract funds substantially. ${ }^{19}$

As a result of these positive developments at the tribal level and, in part, because of the power of economic resources in our political system, the federal political branches have responded. While the United States, since its first Indian treaties, has had a "government-togovernment" relationship with tribes, the relationship has become more meaningful and somewhat more equal. Under the federal policies of self-determination and self-governance, the tribal role in implementing federal responsibilities was broadened beyond the Indian programs at the Department of the Interior and the Indian Health Service at Health and Human Services in the I980s and I990s, to other agencies of Interior, such as the Bureau of Land Management, the

\footnotetext{
154 History OF INDiAn-White RELATiOnS 275 (Wilcomb E. Washburn ed., ig88) ("In I983, it was estimated that more than 80 percent of some ${ }_{5}, 000$ Bureau [of Indian Affairs] employees were Indian.").

16 See Indian AfFairs, U.S. Dep'T of the Interior, Budget Justification AND PERFORMANCE INFORMATION: FISCAL YEAR 20I4 app. I, https://www.indianaffairs.gov/cs /groups/xocfo/documents/text/idc I-02 I 730.pdf [https://perma.cc/8QFY-GPCM] (reporting that the BIA staffed 9044 employees in 2012 and 8677 employees in 2014).

17 News Release, Nat'l Indian Gaming Comm'n, Live from Indian Country, the NIGC Announces Largest Tribal Revenue Gain in Io Years (July I9, 20I6), http://www.nigc.gov/news /detail/live-from-indian-country-the-nigc-announces-largest-tribal-revenue-gain-in [https://perma .cc/CQK9-QZ98] (noting that 238 [of the ${ }_{567}$ ] tribes have gaming operations).

18 NAT'L Indian Gaming Comm'n, Gross Gaming Revenue Trending, https:// www.nigc.gov/images/uploads/reports/20I5_Gross_Gaming_Revenue_Trending.pdf [https://perma $\left.. c c / 3 \mathrm{C}_{9} \mathrm{M}-\mathrm{CX} 9 \mathrm{E}\right]$.

19 For some tribes, Indian gaming provides far more revenues than the federal government ever provided. Federal appropriations through the Department of the Interior (representing the Bureaus of Indian Affairs and Indian Education), the Department of Health and Human Services (representing the Indian Health Service), and the Department of Housing and Urban Development for Indian housing programs, which account for the largest federal programs, together reach less than $\$$ Io billion annually in comparison to nearly $\$ 30$ billion in gaming revenues. Id. Gaming monies are much less evenly distributed than federal program funds, of course, because revenues vary dramatically among gaming tribes and the majority of tribes do not engage in gaming at all.
} 
Fish and Wildlife Service, and the National Park Service, ${ }^{20}$ and also to other cabinet-level agencies, such as the Environmental Protection Agency (EPA), ${ }^{21}$ and even the Department of Housing and Urban Development (HUD). ${ }^{22}$ For many EPA programs, tribes may be treated "as states" for purposes of setting standards and operating programs. Congress appropriates approximately $\$ 650$ million each year to HUD to support tribally run housing programs. ${ }^{23}$ In recent years, Congress has restored the right of tribal governments to exercise felony tribal criminal jurisdiction over their own members and other Indians. ${ }^{24}$ It has even restored criminal jurisdiction over non-Indians in a narrow range of circumstances. ${ }^{25}$ And while tribes can contract to run federal programs under federal standards as discussed above, Congress has, in some cases, enacted laws that authorize tribes to replace federal standards with their own tribal standards. ${ }^{26}$

Tribes have responded positively to the expansion of power. Indeed, tribes have agitated for more and more authority. Many tribes long ago developed capacities far beyond any perceived need for the "federal control" aspects of the trusteeship. ${ }^{27}$ Indeed, in business negotiations or litigation with the federal government, it is not unusual for a tribe to have professional representatives and employees who are equal to the talent on the federal side of the table.

20 Indian Self-Determination Act Amendments of 1994, Pub. L. No. I03-4I3, I08 Stat. 4250 (noting that the act was designed "to provide for tribal Self-Governance"); see also Indian SelfDetermination and Education Assistance Act Amendments of 1988, Pub. L. No. 100-472, I02 Stat. 2285, 22 96; Strommer \& Osborne, supra note I2, at 38-39.

21 See 33 U.S.C. § I 377 (e) (20I2) (Clean Water Act); 42 U.S.C. § 300 -I I(b)(I) (20I2) (Safe Drinking Water Act); 42 U.S.C. § 760I(d) (Clean Air Act); 42 U.S.C. § 9626(a) (Comprehensive Environmental Response, Compensation, and Liability Act).

22 Native American Housing Assistance and Self-Determination Act of 1996 (NAHASDA), 25 U.S.C. \$§ 4IOI-4243 (20I2). NAHASDA established a single federal flexible block grant for tribes or tribally designated housing entities to design and administer housing assistance to tribal members. Id. § $4 \mathrm{II}$ I.

23 U.S. DeP'T OF Housing \& URBAN DeV., FY 2013 BUdGeT 9 (20I3) ("The Budget provides $\$ 650$ million for the Native American Housing Block Grant program, which will provide much-needed funds to more than 550 Tribes to help mitigate severe housing needs and overcrowding on reservations.").

2425 U.S.C. $\$ 1302(\mathrm{~b})$.

25 Violence Against Women Reauthorization Act of 2013, Pub. L. No. II3-4, tit. IX, sec. 904, $\S 204(\mathrm{~b})(\mathrm{I})$ ), I27 Stat. 54, I2 I (codified at 25 U.S.C. $§$ I304(b)(I) (Supp. I 20I4)) (restoring tribal criminal jurisdiction over non-Indians who commit certain acts of domestic violence on Indian lands).

26 See, e.g., HEARTH Act of 2012, Pub. L. II2-I5I, I26 Stat. II50 (codified at 25 U.S.C. $\S 4 \mathrm{I} 5$ ) (creating voluntary alternative business leasing options for tribes where tribes can negotiate and enter into leases without further approval).

27 Kevin Gover, An Indian Trust for the Twenty-First Century, 46 NAT. ResourCES J. 3I 7 , 335 (2006) ("In large measure, Tribes and their members have been relieved of the intrusive federal presence of the past with no withdrawal of federal support...." (quoting Special Message on Indian Affairs, supra note Io, at 567 )). 
As a result of a significant federal political commitment to tribal self-governance, complemented by successful economic development for some tribes, tribal governments have seen a major resurgence in authority and legitimacy. While the sovereign status quo ante, prior to the arrival of Columbus in the Western Hemisphere, may be impossible for tribes to achieve, tribal governments are now much more fully woven into the tapestry of federal, state, and local governmental institutions that cover the United States. Indeed, at least some tribal governments are stronger now than they have ever been in the history of the United States. As a result of the tribal renaissance, Indian people have seen dramatic improvements in federal and tribal governmental services.

The broader normative justifications for the tribal selfdetermination policy lie in classical liberal political theory and moral philosophy, but the specific details have been worked out in the political milieu of federal Indian policy. Though the normative justifications are idealistic and profound, the benefits are intensely practical. The broad consensus is that tribal self-determination contracting has dramatically improved federal services to Indian people.

Why does tribal self-determination deliver services more effectively than the old model characterized by federal control? In part, it is because tribal officials have a significant comparative advantage over federal officials in understanding and meeting the needs of Indian country: they are more accountable to tribal constituents, more knowledgeable about tribal problems and culture, and, significantly, can often provide federal services more economically and more efficiently than the federal government.

In addition to these practical and comparative advantages of tribal governments, numerous less tangible factors are also at play. For example, minor policy decisions are presumably made every day in the operation of government programs. Unlike federal employees and federal policies, which naturally tend to a more uniform, national approach, tribal officials can make their own implementation decisions. Indeed, some of these decisions need not be uniform across the country but can be made slightly differently on different reservations. Tribal officials who have made their own implementation decisions are more likely to be invested in the success of these programs. Moreover, a federal program may simply work better with more flexibility and localized decisionmaking.

Routine tribal operation of federal programs has also had salubrious effects on tribal governments. Through running federal programs, tribes have not only become much more sophisticated in providing services, but also have improved tribal capacities for responsible administration, such as budgeting, enforcing internal controls, and undergoing audits. In other words, the growth in tribal administrative 
and governmental capacity has produced significant secondary benefits beyond simply the contracted federal programs.

Moreover, tribes are becoming much more invested in tribal governance and administration. For years, tribal governments blamed federal entities for continuing social problems on Indian reservations. Since the federal government asserted its own trust responsibility for Indians while simultaneously weakening and undermining tribal governments, the blame was righteous.

Now that tribes are much more empowered, tribal leaders continue to complain about failures of the federal government in meeting the trust responsibility, but they are much more likely to address the criticism constructively with genuine efforts to solve reservation problems themselves. Moreover, since tribes are more committed to providing direct services to their people, they are more willing to direct their own financial resources toward those services, like education, that have been promised them in treaties or under the trust responsibility. The result is a virtuous cycle in which tribes have earned more responsibility and power from the federal government and, in turn, they have risen to the occasion for their own people and continued to improve.

\section{MODERn DEVElopMents IN THE TRUST DOCTRINE IN THE COURTS}

The renaissance in tribal self-governance is, of course, new. For most of American history, the federal trust responsibility embodied paternalism. The notion of the "trust responsibility" to Indian tribes dates from Chief Justice John Marshall's opinions in a series of foundational American Indian law cases, now known as the Marshall trilogy. ${ }^{28}$ He famously characterized the relationship between the United States and tribes as a guardian-ward relationship. ${ }^{29}$ While Chief Justice Marshall recognized tribes as "nations," he viewed them as inferior "domestic" nations "dependent" on the United States for their existence and protection. ${ }^{30}$ Chief Justice Marshall divined his formulation of the trust responsibility from international law and early federal statutes, such as the Indian Trade and Intercourse laws, which federalized relations with Indian tribes and provided for significant federal oversight of trade with Indians. ${ }^{31}$

Since the Marshall era, the trust doctrine has been "one of the cornerstones of Indian law."32 Applying the doctrine, the Supreme Court

\footnotetext{
28 Worcester v. Georgia, 3I U.S. (6 Pet.) 5 I5 (I832); Cherokee Nation v. Georgia, 30 U.S. (5 Pet.) I (I83I); Johnson v. M'Intosh, 2 I U.S. (8 Wheat.) 543 (I823).

29 Cherokee Nation, 30 U.S. at I 7.

30 Id.

$31 \mathrm{Id}$. at $\mathrm{I} 7-\mathrm{I} 8$.

32 Cohen's HandBook, supra note $5, \S 5.04[3][\mathrm{a}]$, at $4 \mathrm{I} 2$.
} 
has held the United States to "the most exacting fiduciary standards." 33 The Supreme Court and the lower courts have thus sometimes provided a modest check on American political ambitions related to manifest destiny and provided some comfort to tribes with rights recognized in laws, treaties, and broader notions of justice.

The political branches, for their part, have implemented the trust responsibility in a multitude of federal statutes that now constitute five full volumes of the United States Code bearing the word "Indians" on their spines. Many of these statutes, especially the early ones, infantilized Indians and Indian tribes, treating them as wards of the federal officials who should make most of the important decisions for them. In nineteenth-century Indian policy, the President was sometimes characterized as the Great White Father, furthering the paternalistic nature of this relationship.

Courts have enforced these paternalistic laws and sometimes have also served as the conscience of the nation in its dealing with Indian tribes. The courts insured that many of the nation's legal promises to Indian tribes were met, even when it was politically unpopular to do so. To be sure, the courts enforced American promises imperfectly and inconsistently, but they have often protected tribes when political actors failed. Consider, for example, the Sioux Nation case in which tribes sued the United States for the taking of the Black Hills and were awarded what was then the largest judgment against the federal government in United States history. ${ }^{34}$ Or consider the fishing rights cases of the I970s in which federal courts protected the treaty fishing rights of tribes and tribal members in the Midwest and the Pacific Northwest, ${ }^{35}$ and the 1999 Supreme Court decision upholding the offreservation hunting, fishing, and gathering rights of the Mille Lacs Band of Chippewa Indians. ${ }^{36}$

In the last fifty years, as noted above, federal Indian policy has undergone dramatic changes. Tribes have increasingly been recognized as self-governing sovereigns that can make their own decisions. These developments have raised a new question: what is the role of the Great White Father and the courts in this new era?

Tribal governmental advancements have disrupted the longstanding formulation of the trust doctrine and have reconfigured the judicial

\footnotetext{
33 Seminole Nation v. United States, 316 U.S. 286, 297 (I942).

34 See United States v. Sioux Nation of Indians, 448 U.S. 37 I (I980) (affirming \$106 million judgment against the United States in favor of the Sioux Nation); see also EDWARD LAZARUS, Black Hills/White Justice: The Sioux Nation Versus the United States, i 775 TO THE PRESENT 38I-402 (I99I).

35 See, e.g., United States v. Washington, 459 F. Supp. 1020, 1028 (W.D. Wash. I978); see also Charles Wilkinson, BloOd StrugGle: The Rise of MOdern INDiAN NATIONS I5773 (2005).

36 Minnesota v. Mille Lacs Band of Chippewa Indians, 526 U.S. I 72, I 76 (I999).
} 
role in the trust responsibility. In a series of cases, most notably, the United States $v$. Mitchell cases of the early I 980 s and a pair of 2003 cases, United States v. Navajo Nation ${ }^{37}$ and United States v. White Mountain Apache Tribe, ${ }^{38}$ the Supreme Court set aside the broader moral context of the relationship between the federal government and tribes and employed a much narrower approach in interpreting whether there is a legally enforceable federal trust responsibility to tribes.

In United States v. Mitchell ${ }^{39}$ (Mitchell I), the Court found that an Indian trust statute was not sufficient to create an enforceable fiduciary responsibility even if it specifically included the legal term of art "trust." 40 In a later opinion in the same case (Mitchell $I I^{41}$ ), however, the Court recognized that a specific statutory and regulatory regime that gave the government pervasive and comprehensive control over tribal resources was sufficient to establish a legally enforceable trust responsibility. ${ }^{42}$ The Court clarified that money damages for breach of trust are available only if a law establishes a "substantive right enforceable against the United States for money damages"43 and the plaintiff cites a source of law that is relatively clear in mandating compensation. ${ }^{44}$

In sum, the Mitchell cases clarified that neither the general historic federal trust relationship with tribes nor the bare trust created by the government's ownership of "trust" lands created an enforceable trust responsibility. However, statutes establishing a regulatory regime with active and pervasive federal management of tribal resources could create an enforceable trust claim. But the outcomes of that framework at that time may have been limited because the Mitchell cases were decided when federal control of reservation remained pervasive. ${ }^{45}$ At that time, nascent efforts toward tribal governance of trust resources were only beginning to gain footing. ${ }^{46}$

By the early 2000 s, tribal self-governance efforts were well under way and federal policy began to exhibit ambivalence about the paternalistic and protective role of the federal government. In Navajo Nation, the Supreme Court further clarified the scope of the trust responsibility. In that case, the Navajo Nation had undertaken the re-

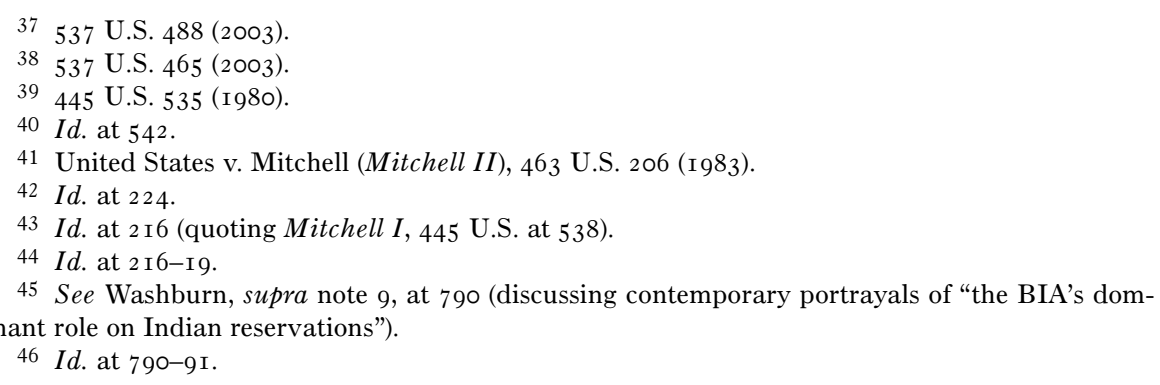


sponsibility, under a statute that fostered tribal self-governance, to negotiate royalties for coal from a coal mining company. ${ }^{47}$ Though the tribe could negotiate the rate, only federal officials could formally approve it. ${ }^{48}$ Thus, the federal government retained some power to oversee the economic relationship and protect the tribal interest.

In an episode that became embarrassing for the federal government, the coal company sought and received a private meeting with the Secretary of the Interior, Donald Hodel. ${ }^{49}$ In a letter to the Secretary and in the private meeting (without the Tribe present), the coal company lobbied the Secretary to reject the Tribe's negotiated increase and to send the parties back to the negotiating table. ${ }^{50}$ The Secretary, through a deputy, informed the parties that he would not immediately decide an appeal raised by the coal company. ${ }^{51}$ Facing severe economic pressure and the prospect that the very low existing rate would continue indefinitely, the Tribe agreed to accept a statutory minimum royalty rate. ${ }^{52}$

When the Tribe learned of the secret political influence, it brought a breach of trust action against the United States, citing Secretary Hodel's meeting and actions. ${ }^{53}$ Condemning the Secretary's conduct, the United States Court of Appeals for the Federal Circuit found a breach of trust and ordered a determination of damages owed the Tribe. ${ }^{54}$ The Supreme Court, however, reversed. ${ }^{55}$ It found no statutory requirement that the Secretary act in the Tribe's best interest. ${ }^{56}$

How could the trustee avoid the requirement to act in the beneficiary's best interest? In explaining its opinion, the Supreme Court highlighted the new legal environment spawned by federal policies favoring tribal self-determination. Noting that the relevant statute sought to "enhance tribal self-determination by giving the Tribe[]" the "lead role in negotiating mining leases," the Court noted that "the ideal of Indian self-determination" is "directly at odds with Secretarial control over leasing." $"$ It It appeared to the Court that the freight train of tribal self-determination had rolled over and killed the federal trust responsibility.

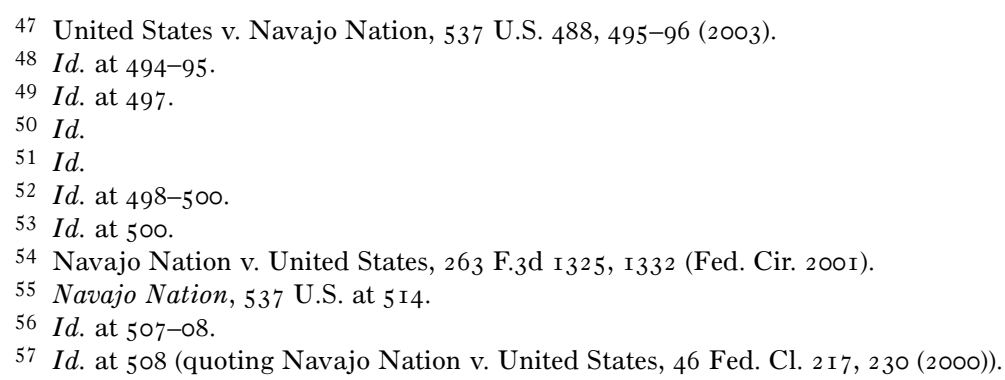


In White Mountain, which was handed down on the same day as Navajo Nation, the Supreme Court showed, however, that the trust responsibility was narrowed but not dead. The Court found federal liability in circumstances of pervasive and exclusive federal control of Indian property. ${ }^{58}$ In this case, the federal government had used Indian trust property for its own purposes and had allowed the buildings that were part of the trust corpus to fall into utter disrepair. ${ }^{59}$ The Court found that the federal government's actual use of the property, to the exclusion of the tribal owners, was sufficient to make the federal government responsible for damages it caused. ${ }^{60}$

Taken together, White Mountain and Navajo Nation suggest that the federal government will continue to be accountable to tribes if it has retained wholesale control over Indian resources, but is much less accountable if it has surrendered a measure of power. In other words, it seems that the trust responsibility exists, but only in situations in which tribal self-determination does not.

The Court's understanding in Navajo Nation that "Indian selfdetermination is at odds with Secretarial control" deserves greater attention. ${ }^{61}$ The two concepts certainly coexist uneasily. The so-called plenary power of Congress in Indian affairs is generally justified on the basis of paternalism - the notion that Indian tribes need the federal government to protect their interests. ${ }^{62}$ One wonders why Congress sought to preserve secretarial control through the secretarial approval power, if that power could be used in such a manner. Indeed, in this instance, the Secretary's actions undermined both the trust responsibility and tribal self-determination. The Secretary failed to act in the best interest of the tribe as a trustee and also harmed tribal self-governance by undermining the Tribe's negotiation position.

The tension between the federal trust responsibility and the idea of tribal self-governance is natural. Power, it is sometimes said, is a zerosum game. ${ }^{63}$ And thus, the significant question remains whether the trust responsibility has any value to tribes if tribes are subject to federal control for which the federal government is not legally accountable. Put bluntly, is the trust responsibility of any continuing value?

\footnotetext{
58 United States v. White Mountain Apache Tribe, 537 U.S. 465, 475-76 (2003).

59 Id. at $469-70$ \& 470 n.2.

60 Id. at $474-76$.

61 Navajo Nation, 537 U.S. at 508 (quoting Navajo Nation, 46 Fed. Cl. at 230).

62 See Mary Christina Wood, Indian Land and the Promise of Native Sovereignty: The Trust Doctrine Revisited, I994 UTAH L. REV. I47 I, I550. See generally Gover, supra note 27.

63 The idea, if not in these specific terms, was discussed by political theorist Thomas Hobbes. See Thomas Hobbes, The Elements of Law: Natural and Politic 26 (Ferdinand Tönnies ed., Cambridge University Press I 928 (I640)).
} 


\section{THE TRUST RESPONSIBILITY TODAY}

The trust responsibility grew out of an assumption famously advanced by Chief Justice Marshall that tribal governments were "nations" but that Indian people were inferior to Americans. ${ }^{64}$ Because it is rooted in paternalism, the trust responsibility seems anachronistic in an era of robust tribal self-governance. Perhaps, in this way, the Court was correct to note this inherent tension in Navajo Nation. ${ }^{65}$ As the government-to-government relationship between the United States and tribes becomes more robust and tribal governments become more empowered, tribes no longer need the "protection" of the federal government as a trustee. That paternalistic control, however, is merely one aspect of the trust responsibility.

The inconvenient fact is that the United States continues to occupy Indian lands. While the paternalistic aspects of the trust responsibility are no longer justified, if they ever were, the moral obligations of the United States owed for taking Indian lands are as great as ever. Indeed, today, the trust responsibility has come to represent something else entirely. It is to the modern and more useful conceptions of the trust responsibility that this Essay now turns.

A striking change in federal Indian policy during the last several decades has been the strong federal support for the resurgence of tribal self-governance. Tribes have persisted, and indeed, have often agitated for more power. But, in recent years, the federal government has sometimes offered them even more than they sought. Consider the political situation facing a tribal leader around criminal justice issues. Most Indian tribes can be characterized as poor, minority communities. ${ }^{66}$ It may not be good political strategy for the tribe's leader to seek more power to imprison his own people. Thus, it was not primarily tribal leaders but Indian activists and, in part, federal officials who sought greater tribal criminal justice authority for tribes. After decades of possessing only misdemeanor criminal sentencing authority, felony criminal jurisdiction was restored to tribes in 2010.67 Another exhibit in the evolution in federal Indian policy is the United States's acceptance of the United Nations Declaration on the Rights of Indigenous Peoples. ${ }^{68}$ This international instrument strengthens notions of

\footnotetext{
64 See Wood, supra note 62, at 1498 \& n.I23 (describing two sides to the trust responsibility, one representing a "sovereign trusteeship," $i d$. at I498, designed to preserve tribal sovereignty, and the other reflecting the paternalistic "guardian-ward relationship," $i d$. at I498 n.I23).

65 Navajo Nation, 537 U.S. at 508.

66 See Washburn, supra note 9, at 786 (identifying "the poverty on many Indian reservations").

67 See Tribal Law and Order Act of 20Iо, Pub. L. No. I I I-2 I I, tit. VII, § 234, I24 Stat. 2258 , 2279-8I (codified as amended at 25 U.S.C. § I302 (2012)).

68 G.A. Res. 6I/295, annex, Declaration on the Rights of Indigenous Peoples (Sept. I3, 2007) [hereinafter U.N. Declaration on the Rights of Indigenous People]; see President Barack Obama,
} 
tribal self-governance by recognizing collective rights of groups as human rights that are as important in many ways as individual rights. ${ }^{69}$

It is now clear that, through a gradual evolution in federal law and policy, the federal trust responsibility has come to represent several significant principles that are unrelated to ancient notions of paternalism. First, the trust doctrine now appears to encompass the obligation to protect the inherent sovereignty that tribal governments never ceded. Second, it has begun to include the notion that the United States should not interfere with internal tribal matters. Third, it now incorporates the understanding that the United States must never take an action affecting Indian tribes without first consulting with them. Finally, it now covers the principal justification for robust fiscal support for tribal governments. Today, the trust responsibility, in effect, constitutes the obligation to foster and protect tribal self-governance. It is to each of these subjects that this Essay now turns.

\section{A. The Trust Responsibility as a Source of Noninterference with Tribal Prerogatives}

Federal support for tribal self-governance coincided with the development of an important norm designed to protect some of the prerogatives of tribes from second-guessing by federal decision makers. This new federal approach might be called the "norm of noninterference with internal tribal governance." The most significant expression of this norm occurred at the dawn of the era of tribal selfdetermination in Santa Clara Pueblo v. Martinez. ${ }^{70}$

In Martinez, the Santa Clara Pueblo's tribal government had enacted a tribal ordinance that allowed the children of Pueblo men to be enrolled, even if the other parent was not a Pueblo member, but disallowed the enrollment of children of Pueblo women who had married outside the Pueblo. ${ }^{71}$ Julia Martinez brought a civil rights action against the Pueblo for refusing to enroll her children, whose father was Navajo. ${ }^{72}$ Against compelling claims of gender discrimination, Justice Thurgood Marshall's majority opinion noted that "[a] tribe's right to define its own membership for tribal purposes has long been recognized as central to its existence as an independent political communi-

\footnotetext{
Remarks by the President at the White House Tribal Nations Conference (Dec. I6, 2010), https://www.whitehouse.gov/the-press-office/2010/I 2/I6/remarks-president-white-house-tribal -nations-conference [https://perma.cc/8TLG-725U].

69 See U.N. Declaration on the Rights of Indigenous Peoples, supra note 68.

70436 U.S. 49 (1978).

71 See id. at 52

72 See id. at $52-53$.
} 
ty." 73 Consequently, the court rejected federal "interference with tribal autonomy and self-government" in such matters. ${ }^{74}$

Martinez reflected an agonizing clash of competing values. In Martinez, the principle of noninterference with tribal sovereignty prevailed over legitimate and important concerns related to human rights and gender equality.

Martinez has come to reflect the notion, widely respected in the courts, that the federal trust responsibility creates a high fence around a significant policy space where tribes are entitled to make their own decisions and retain the last word. The policy space is most protected by this norm when the matters at issue are purely internal or have a significant effect on the tribe's existence or identity. ${ }^{75}$

In sum, the trust responsibility has come to include a new norm against federal interference with tribal decisions. This norm, though controversial from a human rights point of view, ${ }^{76}$ is key to reversing the old paternalistic approach to the trust responsibility, in which a federal executive branch official or a federal court could overrule a tribal government for its own good.

\section{B. The Trust Responsibility, the Government-to-Government Relationship, and Consultation}

Tribes have long had a governmental relationship with the United States. What are treaties, after all, but agreements between sovereigns describing a government-to-government relationship? The United States ratified approximately 370 treaties with tribes in the nineteenth century. ${ }^{77}$ The vast imbalance of power between these sovereigns was always part of the context of those treaties, but that imbalance is changing as tribes have developed governing norms employing the same tokens of legitimacy reflected in state and local governments, such as regular elections, career administrators, governments with separation of powers, and robust courts.

\footnotetext{
73 Id. at 72 n. 32 .

74 Id. at 59 .

75 See, e.g., Montana v. United States, 450 U.S. 544, 564-66 (I98I) (recognizing tribal civil jurisdiction over tribal membership and domestic relations, and even over non-Indians in some circumstances if the conduct at issue "threatens or has some direct effect on the political integrity, the economic security, or the health or welfare of the tribe," $i d$. at 566).

76 See Catharine A. MacKinnon, Whose Culture? A Case Note on Martinez v. Santa Clara Pueblo, in FEMINISM UNMODIFIEd 65-68 (I987); Judith Resnik, Dependent Sovereigns: Indian Tribes, States, and the Federal Courts, 56 U. CHI. L. REV. 67 I, 704-IO (I989).

77 Dalia Tsuk Mitchell, Architect of Justice: Felix S. Cohen and the FOUNDING OF AMERICAN LEGAL PluRALISM 22 I (2007).
} 
As discussed above, many tribes long ago outgrew the need for the "federal control" aspects of the trusteeship. ${ }^{78}$ Chief Justice Marshall's "guardian-ward" relationship has been left behind. Today, the relationship between the United States and tribes is more often referred to as a "government-to-government" relationship. It is a much more respectful relationship, characterized more by collaboration and cooperation than federal control.

In 2000, President Bill Clinton issued an executive order directing agencies to engage in consultation and coordination with tribes in "the development of Federal policies that have tribal implications."79 Shortly after taking office, President Barack Obama further directed each federal agency to develop its own individualized plan as to how it would conduct such tribal consultations. ${ }^{80}$ Indeed, in an episode early in the Obama Administration that no doubt delighted absurdists, each federal agency was required to engage in tribal consultation even on how to develop a plan on tribal consultation. ${ }^{81}$ Though the executive mandate for consultation was not originally intended to be an enforceable legal requirement, the consultation norm seems to be gradually morphing into law. Indeed, a handful of courts have engaged in nascent efforts to make the requirement enforceable and to evaluate the quality of actual consultation to insure that it is meaningful. ${ }^{82}$ In addition, since 2009 , tribal leaders have grown accustomed to annual meetings with the President and members of the cabinet. ${ }^{83}$

Today, tribal governments are much more involved in shaping federal policy affecting them. As a result, federal policy has improved. Moreover, as tribal governments engage, they become more competent in evaluating and affecting federal public policy. The result is another

\footnotetext{
78 See Gover, supra note 27 , at 335 ("In large measure, Tribes and their members have been relieved of the intrusive federal presence of the past with no withdrawal of federal support ....”).

79 Exec. Order No. I3,I 75, 3 C.F.R. 304 (200I).

80 Presidential Memorandum on Tribal Consultation, 50 Fed. Reg. 57,88I (Nov. 5, 2009).

81 See, e.g., Tribal Consultations, 77 Fed. Reg. I6,I20 (Mar. I2, 2012).

82 See, e.g, Cheyenne River Sioux Tribe v. Jewell, 3:I5-CV-o3018, 2016 WL 4625672 (D.S.D. Sept. 6, 20I6); Wyoming v. U.S. Dep't of the Interior, I36 F. Supp. 3d I3 I7, I345-46 (D. Wyo. 20I5) ("'[W] ... DOI policies and procedures require extra, meaningful efforts to involve tribes in the decision-making process." (quoting U.S. DEP'T OF THE INTERIOR DEPARTMENTAL MANUAL, 5 I 2 DM 4.4 (2015))), vacated as moot sub nom. Wyoming v. Sierra Club, No. 15-8136, 2016 WL 3853806 (Ioth Cir. July I3, 2016).

83 The Obama Administration annually invited the leader of each tribe to Washington, D.C., to meet with the President and members of the cabinet at an annual White House Tribal Nations Conference. The first occurred in November of 2009, and the eighth in September of 2016 . In addition, in 2013, President Obama issued an executive order establishing the White House Council on Native American Affairs, composed of the leaders of each of the cabinet agencies, such as Treasury, State, and Justice, and the various White House agencies, such as the Office of Management and Budget, to promote federal coordination in carrying out the federal trust responsibility to tribes. Exec. Order No. I3,647, 3 C.F.R. 3 I I (2013).
} 
virtuous circle: tribal governments engage; federal policy improves; and tribal governments, in turn, become even more invested in the engagement. As a result of their invited involvement in the machinery of federal policymaking, tribes are ever more politically engaged and more astute.

One impact of the robust government-to-government approach is a further transformation in the content of the trust responsibility itself. Strong tribal input in shaping federal policy necessarily diminishes the continuing paternalistic tendencies of that policy. The trust responsibility has quite simply come to embody much greater respect. Statutes continue to reflect federal government decisionmaking and oversight of tribes, but the trust responsibility now requires careful communication and consultation with tribes before such decisions are made. Moreover, because the new norms around the government-togovernment relationship explicitly require consultation with tribes on any policy matter that affects them, ${ }^{84}$ the trust responsibility has begun to escape the bounds of Indian policy. As governments and communities in the United States, Indian tribes are, of course, affected by numerous general federal policies. The trust responsibility binds the federal government to consult with tribes about policies even if Indian tribes and people are not the primary target of such policies.

\section{The Trust Responsibility and Adequate Fiscal Support for Indian Tribes}

While Chief Justice Marshall originally phrased the trust responsibility in terms that may call to mind the noblesse oblige of a perceived superior culture to an inferior one, the responsibility sprang not from any general duty from the rich to the poor, but clearly in Chief Justice Marshall's words from a landed people to those from whom the land had been taken. ${ }^{85}$ In other words, the trust responsibility sprung directly from the recognition that the United States was founded on Indian land. As the decades went on and manifest destiny unfolded, tribes grudgingly ceded Indian land, often on the basis of generous treaty promises that later went unfulfilled. For most of the time since Chief Justice Marshall's conception of the trust responsibility, there has been a gap between what the United States has promised and

\footnotetext{
84 See Exec. Order No. I3,I 75 § 3(c)(3), 3 C.F.R. at 305 ("When undertaking to formulate and implement policies that have tribal implications, agencies shall ... in determining whether to establish Federal standards, consult with tribal officials as to the need for Federal standards and any alternatives that would limit the scope of Federal standards or otherwise preserve the prerogatives and authority of Indian tribes.").

85 See Alex Tallchief Skibine, Towards a Trust We Can Trust: The Role of the Trust Doctrine in the Management of Natural Resources, in TRIBES, LAND, AND THE ENVIRONMENT 7, 8-9 (Sarah A. Krakoff \& Ezra Rosser eds., 20I2) (discussing the various theories on the source and meaning of the trust responsibility).
} 
what it has delivered. 86 One might characterize the federal trust responsibility and annual appropriations as "rent" due Indian tribes for the United States "occupying" Indian lands in North America.

One might ask whether the trust responsibility, to provide funding to tribes to meet federal responsibilities, can continue as the more paternalistic "control" aspects of the trust responsibility diminish. The answer is, "of course." More modern American sentiment and rhetoric suggest that the ongoing fiscal trust responsibility reflects general compensation for moral wrongs, such as the loss of culture, homelands, and sovereignty. It provides moral atonement to those directly affected by the yawning chasm between what the United States says about itself as a moral and just nation and the wrongs that it committed across the continent in the name of "manifest destiny."

As tribal governments are gradually restored to their former status as sovereigns in North America and their resources and tax bases are restored, some of the moral justifications for compensation may eventually begin to diminish, but the general "rent" justification will not. ${ }^{87}$ Until the United States ceases to occupy North America and immigrants and their descendants return from whence they came, the strong moral justification for federal funding of tribal governments will continue.

Concomitant with the erosion of the enforceability of the trust doctrine in the courts, the trust doctrine has come to support something much more important for tribes. Indeed, a more fundamental change in federal Indian policy during the last several decades has been the strong federal fiscal support for the resurgence of tribal self-

86 Felix S. Cohen, Original Indian Title, 32 MINN. L. REV. 28, 38-43 (I947).

87 Indeed, for some tribes, the "rent" justification appeared explicitly in treaties. For example, the Treaty with the Ottawa states:

It is hereby stipulated and agreed on the part of the United States, as a consideration for the lands, ceded by the nations aforesaid, in the preceding article, that there shall be paid to the said nations, at Detroit, ten thousand dollars, in money, goods, implements of husbandry, or domestic animals, (at the option of the said nations, seasonably signified, through the superintendent of Indian affairs, residing with the said nations, to the department of war,) as soon as practicable, after the ratification of the treaty, by the President, with the advice and consent of the Senate of the United States; of this sum, three thousand three hundred and thirty three dollars thirty three cents and four mills, shall be paid to the Ottoway nation, three thousand three hundred and thirty three dollars thirty three cents and four mills, to the Chippeway nation, one thousand six hundred sixty six dollars sixty six cents and six mills, to the Wyandotte nation, one thousand six hundred sixty six dollars sixty six cents and six mills, to the Pottawatamie nation, and likewise an annuity forever, of two thousand four hundred dollars, to be paid at Detroit, in manner as aforesaid: the first payment to be made on the first day of September next, and to be paid to the different nations, in the following proportions: eight hundred dollars to the Ottoways, eight hundred dollars to the Chippeways, four hundred dollars to the Wyandottes, and four hundred dollars to such of the Pottawatamies, as now reside on the river Huron of lake Erie, the river Raisin, and in the vicinity of the said rivers.

Treaty with the Ottawa, Etc., I807, art. 2, Nov. I 7, I807, 7 Stat. I05 (emphasis added). 
governance. This support and the law underlying it have given rise to a new aspect of a trust responsibility to tribes. Indeed, while the $\mathrm{Su}$ preme Court has viewed the rise in tribal self-governance as a justification for loosening the obligation of federal officials to act in the best interest of tribes, the Court has been protective of specific fiscal promises to tribes in support of self-governance.

An example is Salazar v. Ramah Navajo Chapter. ${ }^{88}$ Ramah was a nationwide class action, originally filed in the early i990s. The plaintiffs alleged that the United States had breached thousands of selfdetermination contracts by failing to pay full amounts due to tribes under those contracts. ${ }^{89}$ The federal defense was that though Congress had mandated the terms of the contracts and specified certain requirements that tribes be allowed administrative support costs similar to what would have been incurred by the federal government, Congress failed, year after year, to appropriate adequate sums to cover those costs. ${ }^{90}$ After nearly twenty years of litigation, when the case reached the Supreme Court, the Court found the federal government liable for breach of contract. The Court unequivocally held that the United States had a responsibility to pay tribes all the amounts it had promised them in contracts. ${ }^{91}$

The outcome of Ramah was extraordinarily important for the success of the tribal self-determination contracting regime. Ramah serves as an important counterbalance to Navajo Nation. While the Supreme Court failed to protect tribes from misuse of the remaining vestiges of federal control, it did require the political branches to keep their contractual promises to Indian tribes in support of tribal self-governance. Thus, the trust responsibility has also come to be seen as reflecting a norm that the federal government has an obligation to meet its own explicit promises to tribal governments and to insure that they will receive the funding promised them to carry out federal trust functions under contracts.

One of the most powerful practical justifications for tribal selfgovernance is fiscal prudence. Because of the success of selfgovernance programs, it is widely understood that the federal taxpayer gets more value from each dollar spent when tribes are contracted to run federal programs. Moreover, as the "control" aspect of the trust responsibility has receded and given way to tribal self-governance, the "funding" aspect of the trust responsibility has become even more important. Indeed, as tribal governments exercise greater power, the need for financial support often becomes more acute. While tribal

88 I32 S. Ct. 2 I8I (2OI2).

89 Id. at $2 \mathrm{I} 88$.

90 Id.

91 Id. at 2 I 95. 
governments wish for control, they also aspire to excellence, or at least competence. Neither can be achieved without adequate fiscal resources. If federal funding diminishes after tribes agree to take over federal functions, the federal government will have off-loaded an important responsibility and left the scene, leaving tribes holding the (empty) bag.

In Ramah and related cases, ${ }^{92}$ the Supreme Court has shown a willingness to insure that tribal self-governance is adequately funded. As a result, as tribal self-governance has flourished, another new norm has come to animate our political understanding of the trust responsibility: the trust responsibility has become a fiscal principle as well as a legal one. In sum, the United States has the moral, political, and sometimes legal responsibility to provide adequate fiscal resources to insure the success of federal programs run by tribes under tribal selfgovernance programs.

\section{Challenges for the TRUst RESPONSIBILITY IN THE FUTURE}

The diminishment of federal paternalistic control and simultaneous expansion of tribal self-governance and authority have raised significant new issues that will pose challenges to the federal government and to tribes and will continue to shape the trust responsibility in the future. First, vestiges of the old, paternalistic trust responsibility mean that tribal initiatives remain subject to federal approvals, which bring, in turn, federal procedural requirements and federal judicial review. While tribes can make strong arguments that such federal requirements undermine tribal self-governance, tribes are facing their own increased scrutiny and, sometimes, deficits in trust that will make further improvements in the trust responsibility harder to accomplish. Several such challenges are discussed further below.

\section{A. Residual Burdens of the Old, Paternalistic Trust Responsibility}

Tribes today exist in a policy space that is betwixt and between the old trust responsibility and the new. They have embraced selfgovernance and they exercise far more control over their own destinies, but they continue to carry the burdens of federal involvement in - and federal approval of - many important decisions. Indeed, for many tribes, Navajo Nation underscored some of the risks of taking over federal functions. In that case, the "trustee" had used its approval power to undermine the tribe's negotiating position, causing the

\footnotetext{
92 E.g., Cherokee Nation of Okla. v. Leavitt, 543 U.S. 63I (2005) (holding that a tribal selfdetermination contract was binding on the federal government even though Congress failed to appropriate funds for those costs).
} 
tribe to settle for a lower royalty rate than it could have achieved if the Secretary had behaved in the best interest of the tribe, or even if the Secretary had been denied any role at all. In that context, the tribal self-determination provisions in the law provided only limited "selfdetermination," and yet they shielded the trustee from liability for wrongdoing. While Secretary Hodel's reputation was tarnished when the episode came to light, the U.S. government was not held accountable in any way for what appeared to be an inappropriate use of the federal approval power.

Mitchell I and II, together with Navajo Nation and White Mountain, have placed tribes in a difficult position. These Supreme Court decisions suggest that the trust responsibility to Indian tribes has narrowed considerably in the past thirty to forty years, as tribal selfgovernance has taken hold. Today, the trust responsibility is legally enforceable through a suit for damages in only a narrow range of circumstances and perhaps not at all when the tribe is exercising its own powers of self-governance. If the trust responsibility is generally not enforceable in an action for damages, is there really any trust responsibility at all?

Without a doubt, Indian tribes would benefit from even less "Secretarial control" if Navajo Nation is an indication of how that control will be exercised. The Navajo Nation was arguably mistreated by its trustee, but had no recourse for that mistreatment. Navajo Nation left tribes and lawyers more clear-eyed about the trust responsibility and its ability to protect tribes in the era of tribal self-determination. Together, all of these cases suggest that the tribes can have little confidence in the trust responsibility alone to protect the tribe's best interests, but they also demonstrate that a tribe undertakes serious risks when it trusts the federal government's oversight of tribal economic decisions.

The Supreme Court has recognized more recently what has been implicit all along: federal decisionmakers have their own policy goals that may or may not be consistent with tribal goals. ${ }^{93}$ Beneficiary beware; it is now perhaps more clear than ever that the federal trustee may or may not have the tribe's best interests in mind when it makes decisions. ${ }^{94}$ The government's conflicts of interests, while real, are not

\footnotetext{
93 United States v. Jicarilla Apache Nation, 564 U.S. I62, I 74-75 (20I I) (noting that the trust responsibility differs from an ordinary common law trust relationship in part because "the Government has often structured the trust relationship to pursue its own policy goals," $i d$. at I 75).

94 See Reid Peyton Chambers, Compatibility of the Federal Trust Responsibility with SelfDetermination of Indian Tribes: Reflections on Development of the Federal Trust Responsibility in the Tiventy-First Century 27-28 (Rocky Mountain Mineral Law Found., Working Paper I3A, 2005) (noting that the courts have been less inclined to "distinguish between the Secretary's role and duties to Indians under the trust responsibility and her roles and duties in other contexts as a public official," $i d$. at 28 ).
} 
generally legally cognizable. ${ }^{95}$ In any event, the Navajo Nation episode reflects a weakening of the notion of the federal government as a "trustee" for tribes. ${ }^{96}$

The statute in Navajo Nation was not unusual. Even in the era of robust tribal self-governance, the federal government retains significant residual oversight of tribal economic decisionmaking. In part, this is because many of the old paternalistic statutes remain on the books. ${ }^{97}$ It is also because, even when amending such statutes to increase tribal control, Congress almost always preserves a continuing federal role. ${ }^{98}$ Indeed, while many statutes have been amended to eliminate the kind of pervasive federal control that can give rise to federal liability, a strong residual federal role remains. In Indian gaming, for example, a tribe may negotiate a management contract with an outside entity to manage a tribal casino, but under a statute enacted in I988, the federal government must approve the management contract. ${ }^{99}$ What the cases now make clear is that the federal government may not be legally accountable to tribes for misuse of this more limited oversight power. ${ }^{100}$

For tribes, the residual federal role is even more troubling for a different reason. While tribal decisionmaking generally should be subject to tribal decisionmaking norms and presumably should be subject to challenge primarily in tribal forums, such as tribal courts, federal supervision of tribal decisions often brings a host of requirements for adherence to federal norms. For many of these actions, significant rules

95 Ann C. Juliano, Conflicted Justice: The Department of Justice's Conflict of Interest in Representing Native American Tribes, 37 GA. L. REV. I307, I344-45 (2003) (citing Nevada v. United States, 463 U.S. I Iо, I 28 (I983)).

96 See supra p. 3 I 2.

97 See, e.g., 25 U.S.C. § 8I(b) (20I2) (requiring federal approval of encumbrances on Indian lands); id. § 4I5 (requiring federal approval of leases of Indian lands).

98 See Indian Tribal Economic Development and Contract Encouragement Act of 2000, Pub. L. No. Io6-I 79, I I 4 Stat. 46 (codified at 25 U.S.C. \$ 8I).

9925 U.S.C. $\$ 27$ II.

100 To be sure, the United States remains politically accountable. More than a hundred cases with tribes and Indian people were settled during the Obama Administration, amounting to nearly \$1o billion in liability for the federal government. See, e.g., David Bennett, USDA/Keepseagle: Settlement $\$ 680$ Million, Delta FARMPrESS (Oct. 20, 20I0), http://www.deltafarmpress.com /government/usdakeepseagle-settlement-680-million [https://perma.cc/LLD4-5Z $\mathrm{Z}_{3} \mathrm{~S}$; $\quad$ Editorial, Candidate Obama Kept His Promise to Native Americans, N.Y. Times (Sept. 30, 20I6), https:// www.nytimes.com/2016/09/3o/opinion/candidate-obama-kept-his-promise-to-nativeamericans.html [https://perma.cc/ED6S-VB 3 G]; Press Release, U.S. Dep't. of the Interior, Secretary Jewell, Tribal Leaders Mark Enactment of Four Additional Water Rights Settlements for Indian Country (Jan. I3, 20I7), https://www.doi.gov/pressreleases/secretary-jewell-tribal-leaders -mark-enactment-four-additional-water-rights [https://perma.cc/E66N-LXFT]. In light of Mitchell $I$ and $I I$ and Navajo Nation, the settlements can fairly be said to represent the triumph of justice over law. While the federal government committed compelling wrongs in each case, the United States might have defended the cases in litigation for years with no certainty that tribes would ever have obtained damages under the Mitchell-Navajo framework. 
attach to even limited federal involvement through numerous federal procedural statutes. Consider that the National Environmental Policy Act $^{101}$ (NEPA) requires significant review and consideration of environmental consequences of proposed actions by federal officials, including, frequently, mere approvals of tribal initiatives. ${ }^{102}$ Compliance with NEPA is required independently of the scope of any tribal environmental review that has already occurred, ${ }^{103}$ and it is often time intensive. As a result, NEPA is a burden on tribal projects; it necessarily undermines tribal agility in pursuing new initiatives, particularly around economic development. ${ }^{104}$

Moreover, decisions of federal officials also tend to be subject to review in federal courts under federal principles of administrative law, such as the Administrative Procedure Act ${ }^{105}$ (APA). ${ }^{106}$ As a result, a modest residual federal approval requirement coming at the end of a long tribal planning process can become a lever for influencing outcomes of tribal initiatives, and sometimes a hook, through APA litigation to review the federal portion of the decision, to delay or stop the project.

In sum, the residue of federal paternalism continues to pose significant obstacles for tribes. Despite significant improvements in tribal self-governance, many tribal projects effectively continue to remain federal projects as well, simply because a vestige of federal authority continues to exist in an approval process. As a result, tribal governments often face obstacles that are unknown to state and local governments or the private sector.

10142 U.S.C. $\$ \S 432 \mathrm{I}-4347$ (2012).

102 Id. $\S 4332$.

103 See Div. of Envtl. \& Cultural Res. Mgmt., Bureau of Indian Affairs, Indian AfFairs National Environmental Policy ACT (NEPA) Guidebook § i.i (20I2) ("Because the majority of activities on Indian trust lands include Federal funding or approval through the Bureau of Indian Affairs (BIA), the responsibility for complying with NEPA generally falls to the BIA.").

104 One agency, the National Indian Gaming Commission (NIGC), has proposed to address this issue in a modest way, by limiting the decisions to which NEPA applies in its realm. The NIGC has the responsibility of approving management contracts between tribes and outside managers. 25 U.S.C. \$ 27 II. In a draft NEPA Guidelines Manual issued in February 20I5, the NIGC proposed a categorical exclusion for application of NEPA in this context, NAT'L INDIAN GAMING COMM'N, NEPA GUIDELINES DRAFT $\S 3$ (20I5), https://www.nigc.gov/images/uploads /Tribal\% 20Consultation/Consultations20 I5/NEPA\%2oguidelines\% 2odraft.pdf [https://perma.cc/MJ66-WV3N], presumably on the theory that the NIGC's limited role in approving who manages an Indian gaming operation does not justify major environmental review since the identity of the manager of any given casino likely has very little effect on the environment.

105 Pub. L. No. 79-404, 60 Stat. 237 (I946) (codified as amended in scattered sections of 5 U.S.C.).

106 See, e.g., 5 U.S.C. $\$ 702$ (2012) (stating that "[a] person suffering legal wrong because of agency action ... is entitled to judicial review”); $i d$. $\$ 704$ (defining which agency actions are reviewable); id. § 706 (defining the scope of review). 
Tribes can make compelling arguments that, in an era in which tribal self-governance has become a widely respected norm, all of the remaining vestiges of federal paternalism should be excised from the U.S. Code and federal Indian policy. As the next section describes, however, tribes may be victims of their own success. To some commentators, tribes' increasing power and authority may justify more, not less, scrutiny.

\section{B. Increasing Scrutiny of Tribes May Slow the Development of Self-Governance}

Today, tribes are exercising real and significant powers. They are making important decisions. But while tribal self-governance is a vast improvement in the delivery of services in Indian country, the new approach presents new problems. As a result of the newly constituted trust responsibility and the rise of tribal self-governance, the federal government is no longer the only government working - and making weighty decisions - in Indian country. In part precisely because the new tribal self-governance model has been viewed as so successful in reinvigorating tribal powers, tribes have begun to face increased scrutiny. ${ }^{107}$

In short, tribes now must face the same social problems that the federal government has tried for decades to address. It should be no wonder that tribes will sometimes fail too. Perhaps because some of the more difficult questions facing tribes under the new model might be perceived as criticism, few scholars or federal policymakers have directly addressed many of the hard questions that have arisen under the new model of federal policy in which tribal self-governance dominates. Greater scrutiny of tribes, and, in some cases, criticism, is justified.

The federal government faces pressure too. For example, although the federal "noninterference" norm has been crucial to the tribal renaissance, it has come under pressure as tribal governments have become more empowered. After all, tribal governments sometimes commit wrongs too. It is not difficult to find instances of public outrage about actions committed by tribal governments involving their own people. ${ }^{108}$ Controversies occur in a variety of policy spaces, from

107 The doctrine of tribal sovereign immunity has been under relentless assault by litigants as tribal governments act in more powerful ways. See, e.g., Michigan v. Bay Mills Indian Cmty., I34 S. Ct. 2024, 2028 (2014) (upholding tribal immunity); Kiowa Tribe of Okla. v. Mfg. Techs., Inc., 523 U.S. 75I, 753 (I998) (same). Though the Supreme Court has continued to uphold tribal immunity against invitations to undermine it, the challenges continue. See Lewis v. Clark, I35 A.3d 677 (Conn. 2016), cert. granted, I37 S. Ct. 3I (2016).

108 See, e.g., Craig Harris \& Dennis Wagner, The Navajo Nation Accepted More than \$I Billion for Houses. So, Where Did It Go?, ARIZ. REPUBLIC (Dec. I4, 20I6), http://www.azcentral.com /story/news/local/arizona-investigations/20 I6/I 2/I 4/navajo-housing-federal-funds/94563354 [https://perma.cc/TYF6-SCD6]. 
disenrollment of tribal members, ${ }^{109}$ to the kinds of problems that happen every day in state or federal governments, such as police violence, ${ }^{110}$ abuse of the public safety and criminal justice processes, ${ }^{111}$ and ordinary fiscal and political corruption. ${ }^{112}$ If tribes are making decisions, tribes must, of course, be responsible for those decisions. One question is how accountability should be achieved in this context.

Moreover, the issue is complicated by the legacy of past federal policies. In the Allotment era, the United States took land from tribes and gave it to individual Indian people ${ }^{113}$ some of whose heirs remain tribal members. As the United States has forfeited policymaking space back to tribes, the federal government continues to have a legal trust responsibility to numerous individual Indians who own shares of allotted land that is held in trust by the federal government. These people, the heirs of original Indian allottees, continue to number in the thousands or tens of thousands. ${ }^{114}$ How does the shift toward tribal selfgovernance affect these Indian people? Can the United States simultaneously have a robust and respectful government-to-government relationship with tribes and yet come between tribes and its own members when those members own interests in individual trust land?

Other serious questions are those that face any government. Some of these arise from governmental failures. No government succeeds in every endeavor. One needs only open the newspaper or a federal case reporter to see that officials in the federal government, state governments, county and local governments, and, yes, tribal governments, sometimes fail their people, and sometimes in the most important of tasks.

Against the backdrop of the federal trust responsibility, however, failures by tribal governments raise unique questions. One result of the gradual expansion of the tribal sovereign sphere has been a blurring of the lines between what constitutes a federal responsibility and what constitutes a tribal responsibility. Indeed, it is partly federal law and federal resources that have empowered tribes and supported the tremendous renaissance in tribal governments. As the federal govern-

109 See, e.g., James Dao, In California, Indian Tribes with Casino Money Cast off Members, N.Y. Times (Dec. I2, 20II), http://www.nytimes.com/20I I/I 2/I3/us/california-indian-tribes-eject -thousands-of-members.html [https://perma.cc/GG2J-YBZ2].

110 See, e.g., Lisa Desjardins \& Emma Lacey-Bordeaux, Problems of Liberty and Justice on the Plains, CNN (Dec. I3, 2012, I I:36 AM), http://www.cnn.com/2012/08/10/us/embed-america-tribal -justice [https://perma.cc/DK54-6TL4].

111 See id.

112 See, e.g., FBI Agent Helps Protect His Native American Community, FBI (Apr. 7, 2015), https://www.fbi.gov/news/stories/public-corruption-in-indian-country [https://perma.cc/B4VT -YE86].

113 Developments in the Law - Indian Law, I29 HARV. L. REV. I652, I655 n.I6 (2016).

114 See S. REP. NO. I06-36I, at 3I (2000). 
ment increasingly seeks to empower tribes, the federal government arguably bears some responsibility for this action. Moreover, from decades of strong federal control and oversight of Indian tribes, Indian people have been accustomed to turning to BIA officials when they are mad about tribal decisions. In the past, the BIA sometimes obliged. ${ }^{115}$ This undermined tribal self-governance. Today, BIA officials are more reluctant to interfere in internal tribal decisions, but this reluctance means that Indian people may have nowhere to turn.

The problem is exacerbated because many tribal decisions today necessarily involve higher stakes. The responsibility - and impact of an error - in the criminal felony context, for example, is measurably heavier than in the misdemeanor context. As tribes engage in governance more than ever before and become meaningful forces within the regions they occupy, their actions and decisions naturally receive, and perhaps deserve, more scrutiny and attention.

One practical response is that failures are inevitable in any government from time to time, and accountability of officials for those failures is important. Presumably, if the community has the ability to hold the responsible officials accountable, failures will occur more rarely. When they do occur, tribal communities will be more content to live with mistakes by their own elected officials than being forced involuntarily to bear the mistakes of federal officials.

People who have often been supportive of tribal sovereignty as a matter of justice have sometimes had second thoughts when they see tribes exercising sovereign powers. Consider, for example, environmentalists who are upset by tribal natural resources development decisions, ${ }^{116}$ or human rights advocates troubled by tribal disenrollment. ${ }^{117}$

Thus, tribal empowerment raises myriad new questions that are much easier to ask than to answer. Since the federal government underwrites some tribal governmental activities, what is the responsibility of the United States in addressing injustices committed by tribal governments? If a tribe errs while exercising a federal function under tribal self-determination, such as law enforcement, what remains of the federal government's trust responsibilities after the tribe has signed a self-determination contract and taken responsibility for a given federal function? Is the federal obligation simply to pay the tribe accord-

115 See generally Robert McCarthy, The Bureau of Indian Affairs and the Federal Trust Obligation to American Indians, I9 BYU J. PUB. L. I, 4-I4, 39-40 (2004).

116 See, e.g., Dennis Wagner, Navajos Assail Environmentalists, ARIZ. RePublic (Oct. I, 2009, I 2:00 AM), http://archive.azcentral.com/arizonarepublic/local/articles/2009/09/30/20090930navajo -enviro.html [https://perma.cc/542 $\left.\mathrm{D}-\mathrm{M}_{2} \mathrm{~W}_{3}\right]$.

117 See generally Gabriel S. Galanda \& Ryan D. Dreveskracht, Curing the Tribal Disenrollment Epidemic: In Search of a Remedy, 57 ARIZ L. REV. 383 (2015) (providing an in-depth exploration of the "realities of disenrollment," $i d$. at 387 (footnote omitted)). 
ing to the terms of the contract, or is there a broader, residual responsibility that continues in effect? Is the federal government a backstop, or a guarantor that Indian people receive the services required by the trust responsibility, even if the tribe performs the services poorly or fails entirely to perform them? In other words, if the United States has contracted with tribes to meet federal trust responsibilities, which government should be held morally and legally accountable if the trust responsibility is not met? Put another way, does the federal obligation run only to the tribe or beyond the tribe to the ultimate beneficiaries, its citizens? These questions are beginning to arise in a number of different contexts.

I. The Disenrollment Crisis. - A particularly vexing problem in recent years has been the human rights crisis in Indian country related to disenrollment of tribal members. ${ }^{118}$ Reports of tribes disenrolling members have provoked a conversation among some commentators about whether the advances in tribal self-governance and the concomitant withdrawal of federal power have gone too far. Appalled by the actions of tribal governments and sympathetic to those who have been disenrolled, some commentators have urged federal officials, and federal courts, to address unjust tribal actions. ${ }^{119}$

Tribal membership decisions, since at least the I970s, have been viewed as crucial to tribal identity and thus central to tribal sovereignty. Following the clear Supreme Court precedent in Martinez, federal courts have respected the norm of federal noninterference in tribal membership decisions. ${ }^{120}$ That decision has always been controversial.121 Many commentators, even some who are very supportive of tribal sovereignty, would have preferred that the federal courts accept a role as an active forum for tribal violations of human rights. ${ }^{122}$ Others have been appropriately skeptical of the value of reinvolving the federal government in internal tribal disputes after working so hard to restore a semblance of tribal sovereignty and self-governance, even if important questions of tribal human rights are at stake. ${ }^{123}$

118 See, e.g., id. at 404-08; David E. Wilkins, Exiling One's Kin: Banishment and Disenrollment in Indian Country, I 7 WESTERN LEGAL HIST. 235, 258-62 (2004).

119 See, e.g., Galanda \& Dreveskracht, supra note I 7 , at 453-73.

120 See Aguayo v. Jewell, 827 F.3 I2 I3, I229 (9th Cir. 20I6) (declining to interfere in an enrollment question and quoting a federal official saying that "in the exercise of sovereignty and self-governance, tribes have the right, like other governments, to make good decisions, bad decisions, and decisions with which others may disagree").

121 See, e.g., MacKinnon, supra note 76, at 63-69; Resnik, supra note 76, at 672-80; Carla Christofferson, Note, Tribal Court's Failure to Protect Native American Women: A Reevaluation of the Indian Civil Rights Act, iо r YaLe L.J. I69, I70 (I991).

122 See, e.g., Galanda \& Dreveskracht, supra note I I 7 , at 462-73.

123 Professor Wenona Singel, for example, has thoughtfully suggested the formation of an intertribal human rights regime. Wenona T. Singel, Indian Tribes and Human Rights Accountability, 49 SAn Diego L. ReV. 567, 6i I-25 (20I2). 
Several decades after Martinez, recent tribal disenrollments have reignited the question at the heart of Martinez, to wit: should the federal government interpose itself between Indians and their tribal governments and serve as the guarantor of human rights against tribal governments? The old notions of the importance of such decisions to core tribal sovereignty remain substantial. In light of the ongoing and seemingly insoluble immigration debate in the United States, can one imagine the federal government forfeiting its own citizenship decisions to another sovereign? Related questions of immigration and residency played into a potentially disastrous move toward Britain's exit from the European Union.

Today, in Indian country, however, the context is different than it was in 1978 when Martinez was decided. First, to some, the stakes seem higher because money is involved. For tribes who make per capita payments to members, the payments can be thousands or tens of thousands of dollars annually per member. Money raises the stakes, at least from an external perspective; the broader American society outside Indian country can more readily understand the impact of the loss of tribal membership when it is accompanied by the loss of material wealth. Second, some claim that the motives for disenrollment are to enrich the remaining members' share of gaming revenues and increase per capita payments. ${ }^{124}$ Finally, because significant money is sometimes at stake, disenrollment today is more likely to be noticed and bring lawyers and formal judicial processes. ${ }^{125}$

Because of the apparent injustice and outrageous actions of some tribes, efforts to use federal forums to resolve such claims will continue, if only because opponents are frustrated at their inability to obtain action at the tribal level. The federal government has gradually recognized a greater quantum of tribal sovereignty for each tribe. Tribes are becoming fuller and more complete sovereign governments. If tribes are to be true sovereigns, they absolutely must have the freedom to make mistakes and to make policy choices that other sovereigns might find offensive. Some of these may constitute human rights vio-

124 See, e.g., Suzianne D. Painter-Thorne, If You Build It, They Will Come: Preserving Tribal Sovereignty in the Face of Indian Casinos and the New Premium on Tribal Membership, I4 LEWIS \& CLARK L. REV. 3II, 3I3-I4 (20IO). This claim may reflect a lack of familiarity with tribal politics. At least since the arrival of Europeans, tribal politics has been a blood sport; disenrollment may simply be a new way of harming a bitter rival.

125 In other ways, however, the current claims for federal involvement are much less compelling than in Martinez. For the gaming tribes that are engaging in disenrollment, the money at issue is not federal money. It is tribal money earned in gaming, an activity authorized by inherent tribal authority and only grudgingly allowed by federal law. See i8 U.S.C. §§ I I66-I I68 (2012); Indian Gaming Regulatory Act, 25 U.S.C. $\$ \$ 270 \mathrm{I}-272 \mathrm{I}$ (20I2); California v. Cabazon Band of Mission Indians, 480 U.S. 202 ( 1987 ). Thus, a potentially strong legal justification for federal interference is absent. 
lations. But even nation-states are sometimes subject to external influence for violations of international human rights norms.

However, the trust responsibility is a somewhat elastic concept, especially to those tribes without treaties explicitly clarifying federal duties. If a tribe has been restored to a fuller form of sovereignty, and it chooses to exercise that sovereignty in a manner that is deemed offensive to federal policymakers, a political question arises: does the trust responsibility require federal taxpayers to continue providing funding to a sovereign government that commits human rights violations? This question is similar to one that frequently arises in American foreign policy. In sum, for tribes engaging in disenrollment in what appears to be an unjust manner, perhaps the United States should recognize the tribal right to take such action, while also reserving the right to assert diplomatic consequences, which could be fiscal in nature, equivalent to international economic sanctions, or political in nature, such as loss of federal recognition.

2. Public Safety and Criminal Justice. - Similar difficult questions arise in the area of public safety and criminal justice. Police work is the rare instance in which violence (against suspected or convicted offenders) is officially sanctioned. Outside of war, no governmental power is more profound and potentially offensive and harmful, or as controversial. Indeed, wrongful killings by police officers have created a serious atmosphere of crisis in the United States. No area of public policy involves higher stakes and greater interest by citizens.

On many Indian reservations, law enforcement is provided by federal officers. Where tribal law enforcement exists, it is commonly underwritten by the BIA through tribal self-determination contracts and grants from the Department of Justice. Throughout Indian country, in other words, tribal law enforcement is supported by federal appropriations. Indeed, for some purposes, tribal police officers working under such contracts are considered federal officers. Because of the potentially violent nature of law enforcement, questions frequently arise as to official liability for wrongful actions taken by law enforcement officers.

In this area, the blurred lines between tribal and federal authority produce complex questions. If the federal government has contracted with a tribal government to provide law enforcement services to its own people on an Indian reservation, should the federal government provide a forum to a tribal citizen harmed by a tribal officer? Would such a forum be consistent with tribal sovereignty? And aside from the forum question, which government, tribal or federal, should bear the cost of any official liability for death or harm?

As a result of federal laws recognizing inherent tribal authority for prosecutions, and more recently authorizing felony criminal prosecutions and limited prosecution of non-Indians, some tribal judicial decisions in the criminal context are subjected to regular scrutiny by fed- 
eral courts. In these areas of federal Indian policy, federal judicial scrutiny, including by habeas corpus proceedings, is authorized by federal law. ${ }^{126}$

Laws authorizing greater criminal justice authority have had the effect of making federal interference with tribal action more routine. Routine federal review of tribal judicial decisions may, over the long term, erode the principle of federal noninterference with internal tribal matters. Thus, tribal governments that now possess greater sovereign power are also facing greater scrutiny. To exercise greater sovereignty, they necessarily must accept limits to the scope of tribal sovereignty and also accept outside interference by the federal government. These new criminal provisions reflect political compromises as to the scope of tribal sovereignty enacted into federal law.

3. Allottees. - Another area for which the tribal renaissance poses new questions relates to the Indian heirs of original allottees of Indian lands. At the beginning of the twentieth century, millions of acres of land were taken from Indian tribes under federal laws, such as the General Allotment Act, ${ }^{127}$ and "allotted" to individual Indians in parcels of various sizes in an effort to turn Indian families into farmers or ranchers. During the Allotment era, more than Ioo million acres were ultimately taken from tribes, through allotment or sales of surplus lands after each tribal adult member or head of household was deemed to have obtained an allotment. ${ }^{128}$ On the heels of the Allotment era followed the Great Depression, as well as the Dust Bowl in the western United States. As a result, soon after individual Indians became landowners, many of them lost their lands, due to poverty resulting in tax sales. The allotment policy was formally rejected during the New Deal era and no more allotments were made, but by then the loss of land was devastating. ${ }^{129}$ The allotment policy is widely viewed by Indian policymakers and historians as disastrous for the loss of land to tribes and Indian people.

Today, however, more than ten million of the original ninety million acres lost to tribes continue to be owned by the heirs of the original allottees. ${ }^{130}$ These parcels of land are held in trust for these heirs by

\footnotetext{
126 See, e.g., Indian Civil Rights Act of 1968, 25 U.S.C. § I302 (enumerating various civil rights tribal governments owe to their people).

127 Ch. I I9, 24 Stat. 388 (I887) (codified as amended in scattered sections of 25 U.S.C.).

128 S. REP. NO. I06-36I, at 3I (2000) ("A direct result of the [General Allotment Act] was the loss of over I00,000,000 acres of land from the Indian trust land base between I 887 and I $934 . ")$.

129 Indian Reorganization Act of I 934, Pub. L. No. 73-383, ch. 576, 48 Stat. 984 (I934) (codified as amended at 25 U.S.C. $\S \S 46 \mathrm{I}-479)$; see also Inst. FOR Gov'T RESEARCH, THE PROBlem OF INDIAN ADMINISTRATION (I928).

130 Robert J. Miller, Native America, Discovered And Conquered i 70 (2006) ("Allotment continues to have a major impact in Indian country today. ... Individual Indians
} 
the federal government, with many of the parcels held by dozens or hundreds of owners in undivided interests. Because the land is held in trust by the federal government, the United States has a direct legal responsibility to these beneficiaries.

Clashes between individual landowners and the government regulators who would create land use rules, such as zoning restrictions, are common in local governments and are more routine than profound. One key aspect of the tribal renaissance has been much greater deference to tribal decisions about land use and management on Indian reservations. ${ }^{131}$ As tribal self-governance has increased, the interests of the individual heirs of allotments have sometimes clashed with the interests and priorities of the tribes, in the same way a small private landowner's interest may clash with county zoning rules and in the same way individual tribal interests once clashed with federal interests. ${ }^{132}$ Restrictions on the use of lands can have economic implications, as such rules tend to lower the value of the land and limit the productive uses of the land. ${ }^{133}$ In Indian country, the federal government's support for tribal sovereignty and self-governance has the very real potential impact of lowering the value of land in trust for individuals. In such a case, the federal government's more general trust responsibility to support tribal governments runs into its narrow but concrete trust responsibility to heirs of allottees for whom it continues to hold land in trust.

Many, but not all, of the heirs of allottees are members of the tribe on whose reservation the land is located. Those heirs presumably have a voice in tribal government, alleviating the impact of the conflict to some degree, but questions about the federal duties to governments and federal duties to individual Indians remain. As economic development improves in Indian country, these problems will potentially arise more often.

\section{CONCLUSION}

The federal trust responsibility has evolved from a paternalistic obligation to care for Indian people to a tool protecting the boundaries of

\footnotetext{
own about I0.2 million acres of land on reservations left over from the individual allotments of the Allotment era.").

131 See, e.g., Final Rule for Residential, Business and Wind and Solar Resource Leases on Indian Land, 77 Fed. Reg. 72,440 (Dec. 5, 2012) (codified in scattered sections of 25 C.F.R. pt. I62 (20I6)) (providing "greater deference to tribes for tribal land leasing decisions").

132 See, e.g., Jessica A. Shoemaker, Complexity's Shadow: American Indian Property, Sovereignty and the Future, II5 MICH. L. REV. 487, 5I3-I7 (20I7) (discussing the costs of federal and other governmental regulation on individual Indian landowners).

133 Jessica A. Shoemaker, No Sticks in My Bundle: Rethinking the Indian Land Tenure Problem, 63 U. KAN. L. REV. 383, 439-44 (2015).
} 
tribal governmental authority to provide that care itself. But the evolution is incomplete. Moreover, new conflicts and questions are inevitable as the power of tribal governments grows and tribes flex more governmental authority. The questions arising from tribal power will be answered in many different contexts and under different sets of rules. For some of the questions, guideposts already exist. For others, federal policymakers and judges have sometimes been left to construct answers on an ad hoc basis by muddling through specific laws and facts that fail to account for broader and more modern principles, such as norms of respect for tribal sovereignty.

As the formerly paternalistic trust responsibility gives way to a new federal policy favoring tribal self-governance, the role of the federal government on Indian reservations will continue to be debated and modified. During the coming decades, federal policymakers and courts will be forced to decide, in a range of areas, whether the federally supported tribal renaissance justifies more federal oversight of tribal decisions or, in the alternative, stronger allegiance to norms of respect for tribal sovereignty. 